\title{
ОРГАНІЗАЦІЯ І ЗДІЙСНЕННЯ СОЦАЛЬНОЇ ДОПОМОГИ ВРАЗЛИВИМ ВЕРСТВАМ НАСЕЛЕННЯ УКРАЇНИ: ВІД ФІЛАНТРОПІЇ ДО ПРОФЕСІОНАЛІЗМУ
}

Соціальні зміни, які відбуваються в Україні, курс держави на створення соціальних служб для населення, становлення різноманітних соціальних організацій змушує звертатись до багатого історичного досвіду соціальної роботи [17, c. 117-123].

Історія створення і формування основних ідей, підходів, концептів, мети, принципів, технологій, методів і засобів соціального практикування давня і грунтується на поступовому розвитку й удосконаленні уявлень соціуму та окремих особистостей про зміст, структуру, особливості людинознавчої діяльності, про способи налагодження ситуативної соціальної взаємодії.

Система соціальної допомоги пройшла шлях від філантропного підходу в підтримці соціально вразливих верств населення, людей, які потрапили у ту чи іншу скрутну життєву ситуацію, до появи такого виду професійної допомоги, як соціальна робота, що призначена створювати грунтовні умови не тільки для соціального забезпечення громадян, а й для розвитку їхніх можливостей і вміння вибудовувати своє життя, мобілізовувати внутрішні ресурси у здоланні життєвих криз і колізій, позитивно самореалізуватися у громадянському та особистому повсякденні [20, с. 8].

Питання здійснення соціальної допомоги, виникнення та розвитку соціального захисту досліджували такі вчені, як Е. Лібанова, Н. Болотна. Трансформацію ролі держави у забезпеченні добробуту громадян відображено у працях О. Іванової, О. Макарова, С. Злупко, Й. Радецького, Н. Сайко [13, с. 228-232], які також у своїх роботах приділяли увагу дослідженню теоретичних засад та історичним витокам соціального захисту населення [18, с. 60-64].

За роки незалежності опубліковано цілу низку монографій, статей, присвячених історії селянства України. У більшості з них історія селянства розглядається в соціально-економічному чи політичному аспектах, має місце намагання осмислити історичний шлях України. Це стосується історичних праць В. Верстюка [1], В. Даниленка [5], Я. Грицака, В. Калініченка, O. Каденюка, С. Корновенка, С. Кульчицького,
В. Марочка, А. Морозова, О. Реєнта, В. Солдатенка, I. Фаренія, Ф. Турченка та інших.

Історію розвитку соціальної педагогіки та соціальної роботи досліджували І. Звєрєва [6], А. Капська [8], Н. Коляда, О. Кравченко[9, с. 182192], А. Фурман [19, с. 3-7], В. Поліщук [12], О. Шевчук [21, с. 87-95], Л. Березівська та інші.

Питанням організації соціальних послуг в сучасній громаді присвячені і праці О. Безпалько, І. Звєрєвої [7], А. Капської [8], Т. Семигіної [14], В. Сидорова [16] та ін.

Але у більшості праць предметом дослідження були процеси формування та функціонування системи соціального захисту в світі в цілому. Натомість недостатньо висвітленими залишаються питання становлення та розвитку організаційних засад соціального забезпечення на теренах України [18, с. 60-64].

Мета статті: на основі теоретичного обгрунтування наукової проблеми охарактеризувати історичні аспекти розвитку соціальної допомоги сільському населенню на українських землях.

Історія розвитку соціальної допомоги сільському населенню бере свій початок $з$ давніх часів.

Особливістю слов'янських предків була відкритість, згуртованість, високе почуття обов'язку перед громадою. У сучасному суспільстві відзначається втрата цих якостей, тому досвід вивчення періоду найдавніших слов'янських громад цікавий і актуальний у наш час.

$\mathrm{y}$ результаті проведеного дослідження встановлено різні форми допомоги і взаємодопомоги у давніх слов' янських общинах.

Перші з них - культові форми допомоги $i$ підтримки. Серед культових форм допомоги у наших пращурів, перш за все, слід назвати поклоніння певним предметам, що мали сакральні властивості, зокрема колу (колесу). Воно, передусім, означало оберігання від злих духів, було символом певної цілісності, стабільності і грунтовності [20, с. 25-26].

Наступні - общинно-родові форми допомоги й захисту в межах роду, сім' $i ̈$, поселення. У цей час існували як індивідуальні, так і колективні форми підтримки та захисту. Допомога надавалась 
людям похилого віку, сиротам, вдовам (індивідуальна форма захисту), а також родині, сусідській громаді, цілому роду (колективний захист) [4, c. 34-35].

Далі були господарські форми допомоги $i$ взаємодопомоги. В основі їх лежать будь-які форми солідарності; «усяка взаємовиручка», в економічному розумінні форма обміну, що зародилася у первісній громаді з появою у ній поділу за працею та особистою власністю. Ранні форми допомоги та взаємодопомоги спочатку мали ритуальний характер і до XIX ст. зберігалися у вигляді народних свят [4, с. 36-37].

Благодійність не тільки допоміжний засіб благоустрою суспільства, але й умова особистого морального здоров'я. Милостиня потрібна більш «ніщелюбцю», ніж самому жебракові. Для благодійника жебрак був духовним благодійником, кращим Богомольцем. Бідні люди вважалися тими, хто є ближче до Бога. Давня Русь розуміла і цінувала тільки особисту, безпосередню благодійність, що подається 3 руки в руку, потай від стороннього погляду.

Благодійнику потрібно було на власні очі бачити людську потребу, яку він полегшував, щоб отримати душевну користь. Потребуючий повинен був бачити свого благодійника, щоб знати за кого молитися. Багаті люди та можновладці сподівалися врятуватися, відкупити свої аморальні вчинки та політику подачею милостині біднякам.

Благодійник, «христолюбець», не стільки думав про те, щоб доброю справою підняти рівень суспільного благополуччя, скільки про те, щоб підняти рівень власної духовної досконалості. При такому погляді на благодійність допомога бідним була справою окремих осіб, які переймалися ідеями християнської моральності, а не включалась в коло державних обов' язків.

Отже, відмінна риса благодійності «сліпа» роздача милостині. Подаючий не цікавився, чому жебрак ії потребує. Просить людей значить треба йому подати, не пристаючи з розпитуваннями [3].

Давньоруське суспільство, приймаючи християнство, 3 розумінням прийняло другу 3 основних заповідей - любов до ближнього. Своє вираження вона отримала в роздачі милостині. Ідея милостині лежала в основі практичної моралі. Потреба в цьому виховувалася усіма тодішніми засобами духовно-моральної педагогіки.

Церковно-монастирська благодійна діяльність сконцентровувалася на допомозі при монастирях, церквах. Там розташовувалися одні 3 перших притулків для нужденних. Парафіяльна благодійність була відкритою, у ній зосереджувалось все общинне, громадське і церковне життя. Діяльність парафій не обмежувалась тільки наданням допомоги калікам, злидарям, вони здійснювали найрізноманітнішу допомогу - від матеріальної допомоги до виховної та духовної. Парафія також була територіальною адміністративною одиницею. До особливо значимих форм парафіяльної благодійності можна віднести кредити 3 церковної казни грошей, хліба, насіння, які надавались окремим особам, а також громаді, часто під заставу майна [4, с. 46-50].

У XIV - перший половині XVII ст. розвиваються три основні форми соціальної підтримки знедолених: 1) монастирська система підтримки; 2) державна система допомоги; 3) перші світські прояви благодійності.

Починаючи з XIV ст. (другої половини), відбувається об'єднання земель навколо монастирів. Пов'язано це зі зміною характеру монастирського управління - починається переорієнтація життєдіяльності монастирів, які тепер ставлять перед собою, передусім, розв'язання господарських завдань. Це перетворює монастирі у самостійні феодальні вотчини.

Багато заможних жінок (княгині, боярині) або їхні чоловіки спеціально будують монастирі для проведення решти життя в їх стінах. Постриги (у черниці) стали поширеним явищем серед жіноцтва, шлях до монастиря був відкритий для жінок усіх суспільних станів.

Селяни із задоволенням приєднувалися до монастирських маєтків, бо тут вони мали значно кращі умови життя - звільнялися від податків, від юрисдикції місцевої влади, від проїжджих княжих чиновників, яким треба було давати вози, коней, корми, провідників. Крім цього, на старості їм забезпечували притулок у монастирі зі статусом ченця або «більця» (не посвяченого у ченці, але проживаючого у межах монастиря, під його захистом). Це слугувало своєрідним страховим полісом, але для його отримання треба було зробити певний внесок у монастирську скарбницю [4, с. 50-51].

Протест українського народу проти національного, релігійного та соціального гніту трансформувався в особливе військове, державне, політичне, культурно-історичне та педагогічне явище - козацький рух. Запорізька вільна республіка започаткувала самобутні зразки благодійних установ та прояви соціальної опіки.

Українське козацтво виникло у XVI ст. як народність із своїм особливим характером, яка самостійно колонізувала широкі степові простори. У козацькому братстві всі були рівні. Навіть ватажок, наділений диктаторською владою, носив однаковий одяг з іншими членами громади.

Козацький рух викликав до життя унікальне для всієї світової культури явище - козацьку педагогіку, основними завданнями якої стали: 
підготовка фізично-загартованих 3 міцним здоров'ям мужніх воїнів-захисників рідного народу, виховання у молоді українського національного характеру та світогляду, формування високих лицарських якостей, пошану до старших людей, прагнення бути милосердними.

Поступово у суспільну тканину Запорізької Січі проникла соціальна нерівність. Декларована звичаєвим правом теза про рівні можливості усіх членів запорізького товариства у реальному житті виглядала у кращому випадку як утопія.

Отже, саме у діяльності Запорізької Січі виразно простежуються два провідні напрями суспільної опіки, що мали місце у XV-XVII ст.: особиста благодійність та громадська при збереженні і заохоченні філантропічної функщії церкви.

У період Українського Відродження (XIVXVI століття) здійснювалися світські підходи до опіки над вразливими верствами населення. Отримала поширення приватна благодійність. Очевидно, на Україні досить живучими залишились благодійницькі традиції споруджувати церкви, школи, лікарні, бібліотеки, започатковані князями Київської Русі. Сповідуючи ідеї людинолюбства, а можливо, прагнучи увічнити своє ім'я в історії рідного народу чи протистояти польській шляхті, захищаючи станові інтереси, українські князі, гетьмани, козацька старшина Запорізької Січі та інші покровителі розвитку церкви, освіти та культури будували споруди, що принесли славу Україні.

Серед українського панства були меценати-піонери українського друкарства і шкільництва. Проте вони були швидше винятками.

Завдяки діяльності українських меценатів були закладені школа підвищеного типу в Острозі та Києво-братська колегія, що у 1701 р. отримала офіційний статус Академії.

Острозька школа-академія є однією 3 перших шкіл вищого ступеня в Україні і найвизначнішою серед православних навчальних закладів XVI-XVII ст., що їх відкривали українські магнати. Вона була організована князем Острозьким на його кошти у 1576 р. Від заснування їй призначалась відповідальна історична роль - протистояти колонізаторському впливові на українську та білоруську молодь католицько-єзуїтських навчальних закладів [4].

3 80-х років XVI до початку XVIII століття триває розвиток благодійності в Україні. У той час починають засновуватися та активно діяти братства, які відкривали школи й шпиталі для бідних та утримували їх за власний кошт.

Братства - це загальнонаціональні організації, що створювались навколо церкви, сприяючи культурно-національному відродженню, світські організації, які відстоювали релігійні, політичні, національні, культурні, станові права ук- раїнців. Їм належали великі заслуги у справі збереження української православної традиції, у становленні громадянського суспільства, його етнонаціональної консолідації, у підвищенні рівня освіти і культури.

У 80-х роках XVI століття було створено найвпливовіше перше Львівське Успенське Ставропігійне братство, члени якого розгорнули широку діяльність: придбали друкарню, відкривали школи.

XVIII-XIX ст. - характеризується всебічним розвитком меценатства та спонсорства у сферах культури й освіти не лише «за покликом душі», а й для популяризації своєї персони в суспільстві.

На цьому етапі вагомий внесок у розбудову культури зробили Дмитро Трощинський (у Кибенцях заснував приватний театр, у місті Кагарлику побудував палац, заснував бібліотеку, посадив великий парк, підтримував молодь у здобутті освіти, став одним з ініціаторів видання «Енеїди» І. Котляревського); Слизавета Милорадович (очолювала та утримувала у своїй садибі Добродійне товариство в Полтаві).

Відомий діяч періоду - Григорій Галаган. Він відкрив у Прилуцькому повіті Сокиринське ощадно-позичкове товариство; 1876 року склав детальний план початкового навчання, який був цілком прийнятий земством, і завдяки якому Прилуцький повіт за кількістю учнів займав у 1870-1980-х роках перше місце в Полтавській губернії; пожертвував садибу в с. Дігтярях для побудови ремісничого училища на 100 чоловік 3 відділами: столярно-токарним, ковальським, слюсарним і модельно-ливарним. Пам'яті померлого сина Павла відкрив колегію Павла Галагана у Києві (1871). Це училище існує і сьогодні [21, c. 87-95].

XIX - початок XX ст. вважається «золотою добою» українського благодійництва $з$ огляду на значну кількість меценатів.

Це було спричинено активізацією суспільно-культурної діяльності в Україні через соціально-економічні перетворення: скасування кріпацтва, розвиток ринкових відносин та підприємництва, що є свідченням зародження в Україні підвалин громадянського суспільства. У той період були створені перші благодійні організації. В. Дідушицький, А. Потоцький, Л. Сапега в 1870-1880-х роках у Львові заснували доброчинну організацію імені К. Шайнохи задля допомоги науковцям та літераторам. У той час при Товаристві святої Терези створювались доброчинні заклади: жіночий виправний дім (заснований 1850 року), швацька майстерня, школа-інтернат для дівчат (1858), шпиталь для бідних дітей Святої Coфiï (1860-1878). Меценати та благодійники активно допомагали школам, лікарням, піклувалися про жебраків, покинутих дітей, безприту- 
льних, глухонімих, людей похилого віку, хворих. Здійснювалися численні пожертви закладам освіти через духовні заповіти, стипендіальні фонди, благодійні організації та земства [2, с. 38-42].

3 революцій та громадянської війни Україна вийшла ослабленою економічно, маючи непоправні людські втрати. У цей історично важкий період було організоване Українське товариство Червоного Хреста. Це відбулося в Києві на з'їзді, що проходив 15-18 квітня 1918 року у приміщенні Марійської общини (вул. МаріїнськоБлаговіщенська, 75). У його роботі взяли участь представники Союзу міст і медико-санітарних організацій Союзу земств. Під час голоду 19211923 років Товариство організувало сотні безкоштовних їдалень, надало селянам мільйони продовольчих пайків.

У перше радянське десятиріччя законодавчо було закріплено повне соціальне забезпечення працівників при всіх видах втрати працездатності, а також уперше у світі визначено захист від безробіття. Необхідно надати належне владі, що декларовані соціальні права реалізовувалися практично, хоча, зрозуміло, рівень соціального забезпечення не міг бути високим, що було зумовлено як внутрішніми, так і зовнішніми факторами становлення нової соціально-економічної системи [10].

Добре подбали організатори Голодомору й про те, щоб не допустити виїзду українських селян за межі України, як це було під час голоду навесні 1932 року, коли люди масово їхали в Росію та Білорусію. Аби не дати можливості їм вижити, приймається ряд заходів. Зокрема, на початку 1933 року було вирішено кардинально посилити блокаду українських сіл. У результаті всю територію України оточили військами, заборонили продаж квитків селянам за межі України, попередили їх, що за виїзд без дозволу навіть у сусідній район - арешт, ліквідували в селах будьяку торгівлю. У такий спосіб українські села перетворювались у концтабори.

На тих українських селян, яким у пошуках хліба все ж таки вдавалося перетнути кордон, полювали, як на диких звірів. У російських селах українці просили не дати, а продати борошна чи зерна.

Отже, ті, хто організував цю чорну справу, дочекалися: українське село почало вимирати. Одні люди пухли, інші висихали на тріску і падали, як мухи. Особливо жахливих розмірів набрав Голодомор ранньою весною 1933 року i тривав до нового врожаю. Тоді щодня помирало 25 тисяч людей, щогодини - 1000 чоловік, щохвилини - 17. Трупи лежали по хатах, під тинами, на дорогах [20, с. 70].

3 початком війни 1941-1945 років виходить низка наказів стосовно соціального забезпечення родин фронтовиків. Перший з них датовано червнем 1941 (на четвертий день після початку війни), що регламентував порядок виплати грошової допомоги родинам фронтовиків. У 1942 року внесено уточнення у цей порядок, а в 1943 прийнято постанову Раднаркому СРСР «Про пільги для родин військовослужбовців, які загинули та пропали безвісти на фронтах Вітчизняної війни».

Інший комплекс тогочасних проблем соціальна допомога та соціальна реабілітація поранених. Восени 1941 року створюються комітети допомоги $з$ обслуговування хворих та поранених бійців Червоної Арміі. У 1942 Державним комітетом оборони організовано будинки для інвалідів Великої Вітчизняної війни (пізніше перетворені в трудові інтернати). У них скалічені вояки готувалися до подальшої трудової діяльності, отримували той чи інший фах, проходили перепідготовку. Водночас нових рис і масштабів набувають у цей час і проблеми охорони дитинства та опікування сиротами.

У 1949 році НКС3 перейменовано на Міністерство соціального забезпечення, а наприкінці 50-х починається новий етап розвитку названого забезпечення в СРСР. У 1956 році Верховна Рада приймає Закон про державні пенсії, за яким розширюється коло осіб, яким надається пенсія, окремо створюється законодавство про соціальне забезпечення, започатковується загальне державне пенсійне забезпечення працюючих, яке завершується прийняттям у 1964 році Закону про пенсії та грошову допомогу членам колгоспів. Розмір пенсій за віком для більшості колгоспників був дуже далекий від прожиткового мінімуму

На усіх громадян СРСР поширювалося безкоштовне медичне обслуговування, хоча у різних регіонах і місцях воно було зовсім не однакової якості. На рівні клінік Заходу медичні послуги і засоби отримувала безкоштовно лише партійна верхівка та члени ії родин.

Характерною особливістю соціальноекономічного розвитку СРСР 50-90-х років було підвищення ефективності і якості роботи у всіх галузях народного господарства. Це безпосередньо стосувалося питання раціонального спрямування засобів соціального забезпечення, а також підвищення економічної відповідальності виробничих колективів за найбільш ефективні витрати ресурсів.

Соціальна політика Радянського періоду була спрямована на підвищення матеріального і культурного рівня життя усіх груп населення, у тому числі сімей з дітьми, пристарілих людей, інвалідів, тимчасово непрацездатних робітників. Вступ країни у період так званого розвинутого соціалізму характеризувався прискоренням про- 
цесів вдосконалення системи пенсійного забезпечення, а також інших видів і форм соціального страхування і соціального забезпечення населення [11].

Проголошення суверенітету України поставило перед новою державою завдання реформування системи соціального забезпечення, створення дієвої моделі соціального захисту населення та умов для розвитку громадянського суспільства. Саме в 1990-х роках у країні почали активно створюватися різноманітні державні соціальні служби, територіальні центри $з$ обслуговування самотніх людей похилого віку та інвалідів, які виникли практично в кожному районі. Так само набули поширення соціальні служби для молоді, які спершу були зорієнтовані на соціальну педагогіку й масову роботу із цією віковою категорією населення. Майже ніхто з працівників соціальних служб не мав як грунтовної фахової освіти, так і відповідної соціальнопсихологічної компетентності.

Водночас у цей період державотворення відроджуються благодійність і волонтерство. Відбувається розвиток громадських організацій та груп самодопомоги; створюються клуби й денні центри для дітей-інвалідів та їхніх батьків, для людей із проблемами психічного здоров'я, для наркозалежних тощо. Ці недержавні заклади потребували порад фахівців щодо організації корекційної, адаптаційної роботи персоналу. Крім того, середині 1990-х років властива тенденція до створення недержавних соціальних служб у громадах (прикладом тут є хеседи, які обслуговують людей літнього віку в єврейських громадах, а також київська організація «Джерела», що просуває ідею догляду в громаді для людей із розумовою відсталістю) [15, с. 46-86].

Окрім традиційних будинків-інтернатів, тобто стаціонарних закладів, на рубежі століть почали з'являтися так звані територіальні центри - напівстаціонарні та нестаціонарні заклади. До того ж під впливом фахівців Заходу із соціальної роботи, різноманітних європейських та американських проектів, а також 3 появою в Україні соціальної роботи як фахової діяльності, набули розвитку принципово нові для країни соціальні служби і почали надаватися нові соціальні послуги. Так територіальні центри і відділення соціальної допомоги вдома домінують за останнє десятиліття в наданні послуг літнім людям через державні органи соціального захисту. Кількість цих закладів постійно збільшується.

У маленьких містах та у сільській місцевості практично немає системи комплексного обслуговування підопічних. Тому тут соціальними працівниками базового рівня надаються нужденним лише окремі види допомоги [20, с. 110-111].
У кінці XX - на поч. XXI ст. в Україні 3'явилися об'єктивні чинники змін у системі соціальної допомоги. Розпад Радянського Союзу, неспроможність його політичного та економічного механізмів забезпечувати подальший розвиток суспільства, здобуття Україною статусу незалежної держави викликали потребу створення нового суспільства й нових механізмів соціально-економічного регулювання в економічній, політичній, соціальній та гуманітарній сферах. Україна потребує нововведень, які мають створити міцне підгрунтя для становлення високорозвиненої, соціальної за своєю сутністю, демократичної правової держави, іiі інтегрування у світовий економічний процес як країни з конкурентоспроможною економікою, здатною вирішувати найскладніші проблеми свого соціальноекономічного розвитку.

Формування сучасної системи соціального захисту в країні пов'язане з переходом від командно-планової економічної системи до ринкової. Тому поняття «соціальний захист» у нашій країні почало широко вживатися тільки на цьому етапі, хоча в тій чи іншій формі соціальний захист завжди був властивий суспільству.

Потреба саме в соціальному захисті зумовлена природою ринкової економіки, яка не в змозі забезпечити своїм суб'єктам гарантований дохід і зайнятість. Сукупність факторів спричинили суттєві відмінності в рівні доходів, стану здоров'я, обсязі задоволення потреб населення. Зменшити негативний вплив таких факторів на рівень життя певних прошарків населення й має соціальний захист.

На середину 2010-х років система соціального захисту в Україні загалом продовжувала зберігати окремі риси старої системи й за своїми параметрами не відповідала передовим системам соціального захисту країн Свропейського Союзу. Реформування іiі проводять несистемно: воно не має цілеспрямованого характеру, не спирається на збалансованість розвитку національної економіки й соціальних зобов' язань держави [4].

Сьогодні Україна переживає складні часи у багатьох аспектах суспільного життя - економічному, політичному, правовому, соціальному, світоглядному. Прискореними темпами особистісного уточнення набуває національна ідентичність населення: все більше українцями вважають себе не лише рідномовні громадяни, а й російськомовні, багато з яких виявляють неабиякий патріотизм на Сході [20, с. 120-121].

Отже, соціальна допомога пройшла досить складний шлях змін від філантропного підходу до появи професійної допомоги. Вивчення та узагальнення цього досвіду зараз є актуальним як в науковому плані, так і в практичному застосуванні. 
Подальшого розгляду потребує висвітлення особливостей соціальної роботи в українському селі за умов глибокого теоретичного осмислення і конкретних практичних рекомендацій, апробованих досвідом та самим життям.

\section{СПИСОК ВИКОРИСТАНИХ ДЖЕРЕЛ}

1. Бануца А. В., Бунятян К. П., Ващук Д. П., Верстюк В.Ф. та ін. Історія українського селянства. Нариси: в 2-х т. К.: Наук. думка, 2006. T. 1.632 c.

2. Рощина Л. О. Благодійна діяльність українських братств. Наука. Релігія. Суспільство. 2009. № 1. С. $38-42$.

3. Голимба В. I. Історія благодійництва в Україні. К., 2002. 258 с.

4. Горілий А. Г. Історія соціальної роботи в Україні. Тернопіль: ТАНГ, 2001. 191 с.

5. Даниленко В. М., Романюк I. М. Українське село в добу реформ М. С. Хрущова. Iсторія украйнського селянства. К., 2006. Т. 2.

6. Звєрєва І. Д., Кузьмінський В. О., Киянищя 3. П., Петрочко Ж. В. та ін. Соціальний супровід сімей, що опинились у складних життєвих обставинах: метод. посіб. Київ: ДЦССДМ. 2007. 84 c.

7. Звєрєва І. Д. Соціально-педагогічна робота 3 дітьми та молоддю в Україні: теорія і практика: монографія. К.: Правда Ярославичів, 1998. 333 c.

8. Капська А. Й. Соціальна робота: деякі аспекти роботи 3 дітьми та молоддю. Київ: УДЦССМ, 2001. 219 c.

9. Кравченко О.О. Навчальна дисципліна «Історія соціальної роботи» у процесі професійного становлення майбутніх соціальних працівників. Науковий часопис Національного педагогічного університету імені М. П. Драгоманова. Серія 11: Соціальна робота. Соціальна педагогіка. Київ: Вид-во НПУ імені М. П. Драгоманова, 2018. Вип. 24, Т. 1. С. 182-192.

10. Лукашевич М. П., Семигіна Т. В. Соціальна робота (теорія і практика): підручник. К.: Каравела, 2011. 368 с.

11. Мигович I. I. Соціальна робота (вступ до спеціальності). Ужгород, 1997. 180 с.

12. Поліщук В. А. Соціальна педагогіка як наукова основа здійснення соціальної політики сучасного українського суспільства. Педагогічний дискурс. 2007. Вип. 2. С. 131-135.

13. Сейко Н. А. Доброчинність у сфері освіти в Україні (XIX - початок XX століття): Київський учбовий округ: монографія. Житомир: Вид-во ЖДУ, 2006. С. 228-232.

14. Семигіна Т. Робота в громаді: практика й політика. К.: Академія, 2004. 180 с.

15. Сидоров В. Ролі та функції соціальних працівників. Соціальна робота в Україні: перші кроки / за ред. В. І. Полтавця. К.: КиєвоМогилянська Академія, 2000.

16. Сидоров В. Н. Профессиональная деятельность социального работника: ролевой подход. Винница, 2006. 404 с.

17. Рощина Л. О. Соціальна допомога на українських землях в литовсько-польську добу. Наука. Релісія. Суспільство. 2009. № 4. С. 117-123.

18. Стопчак А. Ю. Історичні аспекти виникнення та еволюції соціального захисту населення в Україні. Вісник Хмельницького національного університету. Серія: Економічні науки. 2010. № 1. T. 1. С. 60-64.

19. Рощина Л. О. Формування радянської системи соціального забезпечення у 20-30-і роки ХХ ст. Наука. Релігія. Суспільство. 2010. № 2. C. 3-7.

20. Фурман A. В., Підгурська М. В. Історія соціальної роботи: навч. посіб. Тернопіль: THEУ, 2014. 174 c.

21. Шевчук О. Історія створення Колегії Павла Галагана. Історико-педагогічний альманах. 2012. Вип. 1. С. 87-95.

\section{REFERENCES}

1. Banutsa A. V., Buniatian K. P., Vashchuk D. P., Verstiuk V. F. ta in. (2006). Istoriia ukrainskoho selianstva: narysy (Vols. 1-2). K.: Naukova dumka [in Ukrainian].

2. Roshchyna, L. O. (2009). Blahodiina diialnist ukrainskykh bratstv. Nauka. Relihiia. Suspilstvo, 1, 38-42 [in Ukrainian].

3. Holymba, V. I. (2002). Istoriia blahodiinytstva v Ukraini. K. [in Ukrainian].

4. Horilyi, A. H. (2001). Istoriia sotsialnoi roboty v Ukraini. Ternopil: TANH [in Ukrainian].

5. Danylenko, V. M. \& Romaniuk, I. M. (2006). Ukrainske selo v dobu reform M. Khrushchova. Istoriia ukrainskoho selianstva. K., Vol. 2. 411-476 [in Ukrainian].

6. Zvierieva I. D., Kuzminskyi V. O., Kyianytsia Z. P., Petrochko Zh. V. ta in. (2007). Sotsialnyi suprovid simei, shcho opynylys u skladnykh zhyttievykh obstavynakh. K.: DTsSSDM [in Ukrainian].

7. Zvierieva, I. D. (1998). Sotsialno-pedahohichna robota $\mathrm{z}$ ditmy ta moloddiu $\mathrm{v}$ Ukraini: teoriia $\mathrm{i}$ praktyka. K.: Pravda Yaroslavychiv [in Ukrainian].

8. Kapska, A. Y. (2001). Sotsialna robota: deiaki aspekty sotsialnoi roboty $\mathrm{z}$ ditmy ta moloddiu. K.: UDTsSSM [in Ukrainian].

9. Kravchenko, O. O. (2018). To the issue of the implementation of the gender approach in the process of training social workers. Naukovyi chasopys Natsionalnoho pedahohichnoho universytetu imeni M. P. Drahomanova. Seriia 11: Sotsialna robota. Sotsialna pedahohika. Kyiv: Vyd-vo NPU imeni M. P. Drahomanova, Issue 24, Vol. 1, 182-192 [in 
Ukrainian].

10. Lukashevych, M. P., Semyhina T. V. (2011). Sotsialna robota. Teoriia i praktyka. K.: Karavela [in Ukrainian].

11. Myhovych, I. I. (1997). Sotsialna robota (vstup do spetsialnosti). Uzhhorod [in Ukrainian].

12. Polishchuk, V. A. (2007). Sotsialna pedahohika yak naukova osnova zdiisnennia sotsialnoi polityky suchasnoho ukrainskoho suspilstva. Pedahohichnyi dyskurs, 2, 131-135 [in Ukrainian].

13. Seiko, N. A. (2006). Charity in the field of education of Ukraine (XIX - early XX centuries). Kyiv Educational District. Zhytomyr: View of the ZhDU them. I. Franko [in Ukrainian].

14. Semyhina, T. V. (2004). Robota v hromadi: praktyka i polityka. K.: Akademiia [in Ukrainian].

15. Sydorov, V. (2000). Roli ta funktsii sotsialnykh pratsivnykiv. Sotsialna robota $v$ Ukraini: pershi kroky. V. I. Poltavtsia (Ed.). K.: KyievoMohylianska Akademiia [in Ukrainian].
16.Sidorov, V. N. (2006). Professionalnaya deyatelnost sotsialnogo rabotnika: rolevoi podkhod. Vinnitsa [in Russian].

17. Roshchyna, L. O. (2009). Sotsialna dopomoha na ukrainskykh zemliakh v lytovsko-polsku dobu. Nauka. Relihiia. Suspilstvo, 4, 117-123 [in Ukrainian].

18. Stopchak, A. Yu. (2010). Istorychni aspekty vynyknennia ta evoliutsii sotsialnoho zakhystu naselennia v Ukraini. Visnyk Khmelnytskoho natsionalnoho universytetu. Seriia: Ekonomichni nauky, 1, Vol. 1, 60-64 [in Ukrainian].

19. Roshchyna, L. O. (2010). Formuvannia radianskoi systemy sotsialnoho zabezpechennia u 20-30-i roky XX st. Nauka. Relihiia. Suspilstvo, 2, 3-7 [in Ukrainian].

20. Furman, A. V., \& Pidhurska, M. V. (2014). Istoriia sotsialnoi roboty. Ternopil: TNEU [in Ukrainian].

21. Shevchuk, O. (2012). History of the College of Paul Halagan. Historical and Pedagogical Almanac, 1, 87-95 [in Ukrainian]. 